\title{
Analysis of the Influence of the Quality of Library Services on Library Satisfaction
}

\author{
Anna Pranita Br Saragih ${ }^{1 *}$, amaluddin $^{1}$, Mahyuni ${ }^{1}$ \\ ${ }^{1}$ Master of Governmental Science, Faculty of Social and Political Science, Lambung Mangkurat University, Banjarmasin, Indonesia
}

DOI: $10.36348 /$ sijlcj.2021.v04i02.009

| Received: 09.02.2021 | Accepted: 22.02.2021 | Published: 26.02.2021

*Corresponding author: Anna Pranita Br Saragih

\section{Abstract}

The aim of this study was to analyze the effect of library service quality on the satisfaction of users at the Library and Archives Service of South Barito Regency, Central Kalimantan. This research uses a quantitative research approach, with the aim of obtaining a deep picture of the analysis of library service strategies. The research sample used was 100 respondents who were users. Data analysis used simple linear regression method. The results showed that the service quality factor based on tangible indicators, reliability, responsiveness, assurance and empathy had quite good categories. The level of user satisfaction based on indicators of overall satisfaction (overall satisfaction) expectations (expectation satisfaction), and trust (expeience satisfaction) has a category of quite satisfied It is recommended to the Regional Library and Archives Service to improve the quality of its services by taking into account direct evidence factors tangible, reliability, responsiveness, assurance and certainty, and empathy so as to increase customer satisfaction.

Keywords: User Satisfaction, Library Service Quality.

Copyright () 2021 The Author(s): This is an open-access article distributed under the terms of the Creative Commons Attribution 4.0 International License (CC BY-NC 4.0) which permits unrestricted use, distribution, and reproduction in any medium for non-commercial use provided the original author and source are credited.

\section{INTRODUCTION}

Based on the 1945 constitution, the fourth paragraph states one of the functions of the state, namely the intellectual life of the Nation .In this case, the role of the government is to ensure the availability of information and provide services to the community in increasing knowledge and knowledge. The library as a means of delivering education is a vehicle for education, a source of information, science, technology, research, recreation, and cultural preservation. The existence of a library is to provide library services to the community quickly and precisely as a place for lifelong learning for all levels of society. In the discussion forum of the Indonesian Ombudsman Bakohumas Forum on managing citizen complaints about prime public services on November 5, 2014, the government is required to provide good public services, because basically in a democratic country the state apparatus is a public servant.

Based on law number 43 of 2007 regarding libraries, library services are carried out in a prime and oriented manner for the interests of the visitors. Library users are library users consisting of individuals, groups of people, communities, or institutions that use libraries built and developed in accordance with their demands. The quality of library services is important to pay attention to because good service quality will increase public interest in reading. The increased interest in reading the community will be able to increase community knowledge. The increased knowledge from the community will be able to make people's lives prosperous. The role of libraries in this century is no longer limited to books only but also includes other printed books that are not books, for example, magazines, newspapers, tapes, films, microfilms, and in digital forms such as electronic journals (e-journals), electronic books (e-books) and so on produced by advances in science and technology [5].

The condition of scientific information management requires that the library as one of the information centers must strive to understand the needs, desires, and requests for information of users, then organize and provide information that is relevant to the needs of these users. In the business world, this effort is known as an effort to maintain customer loyalty by providing a high level of satisfaction to customers. This customer satisfaction is expected to build loyalty which in turn will provide long-term benefits for the company. Likewise, libraries should try to pay more attention to 
Anna Pranita Br Saragih et al., Sch Int J Law Crime Justice, Feb, 2021; 4(2): 89-96

the relationships arising from the routine process of providing services in order to maintain users as library customers; this is intended to build and improve the loyalty of users and to maintain the image of the library as an information provider that does not disappoint users.

Service quality is a unique phenomenon because its dimensions and indicators can differ among the people involved in service. Service quality is what shows the level of service perfection in creating a sense of satisfaction in each consumer. Efforts to improve service quality will be very effective if improving service quality is a daily goal, starting from the top management to service implementers. According to Parasuraman, Ziethmal, and Berry [1] identify a complete set of service attributes which customers can use as criteria in assessing the company's service performance. The assessment of service quality is based on five dimensions of service quality, namely reliability, responsiveness, assurance, empathy, and tangibles. These attributes can be described by being modified according to the type of business understudy and then used as assessment criteria for customers on the performance of service providers. Furthermore, it is stated that satisfaction is the level of feeling in which a person states the results of the comparison of the performance of the product or service received and expected by that person [2].

This means that user satisfaction will be created if the library services received by users are at least comparable to the services provided by the library. Then Khaerunnas and Assauri [4] state that perceived quality is the customer's perception of the overall quality or superiority of a product or service related to what the customer expects. Measuring the level of performance of a service can be done by comparing the expectations of the service with the service performance results achieved, but now there is a tendency to use a subjective measure (soft measure) as an indicator of quality [3]. This measure is called soft because these measures focus on perceptions and attitudes with concrete things called objective criteria. Furthermore, according to Supranto [3] it is often deemed necessary to use soft, subjective measures (someone's opinion), because a more concrete objective index does not apply in estimating the quality of service.

Customer satisfaction is an important measure of service quality in the library. The purpose of research on visitor satisfaction is to develop a reliable measuring tool for user satisfaction in the library. If the library ignores the quality of its services, this will have a negative impact on the interest of visitors to visit the library. In connection with the important role played by the head of the library as a manager and librarian staff in providing quality library services, each library must improve the quality of its librarian human resources.
The quality of Unhas library services can be seen from two sides, namely: first, the things that can support the improvement of the quality of library services are: the average human resources are expert level librarians with S1, S2, and S3 education, so that their competence in providing services is no doubt; The applied information technology is very supportive of the speed and accuracy of service processes such as book return loan service programs, library material processing, and internet access. Second, things that can reduce the degree of service quality are collection of library materials, most of which are old and in English (out of date) publications, obsolete computer equipment, especially those used for tracking installed catalogs (OPAC), often malfunction due to jams / broken.

Central Kalimantan Buntok Library is one of the libraries owned by the Central Kalimantan government. The existence of this library is very much needed by all people of Central Kalimantan. The service standards owned by the library can be said to be less than optimal, where it can be seen based on several things, which include the following;

1. Incomplete vocabulary and reference collections in the library.

2. Circulation system and loan services that are still done manually and simply.

3. Libraries do not promote or socialize about the existence of libraries to the general public and schools.

4. The number of human resources or library management officers is still limited.

According to Martila \& James in Supranto [3], to analyze the level of service performance, the analysis method of the level of importance and performance can be used. The data used for this analysis are the results of a questionnaire on public perceptions of the performance of a service based on predetermined assessment indicators. In this analysis, the $\mathrm{X}$ variable will be used to show the level of performance and the $\mathrm{Y}$ variable for the benefit of the indicator. Starting from the above problems, the researcher feels it is necessary and important to research the analysis of the influence of the quality of library services on visitor satisfaction in the Office of Libraries and Archives, Barito Selatan Regency, Central Kalimantan.

\section{RESEARCH METHODS}

This study uses a quantitative approach because researchers intend to obtain an in-depth picture of the analysis of library service strategies. The method used is a survey by giving questions (questionnaire) to the respondents. This research was conducted at the Office of Library and Archives, South Barito Regency, Central Kalimantan. The data used in this study are primary data and secondary data. Primary data can be obtained through the answers to questionnaires 
Anna Pranita Br Saragih et al., Sch Int J Law Crime Justice, Feb, 2021; 4(2): 89-96

distributed to respondents in the field, while secondary data is an overview of data from in-depth interviews with the leaders of the Buntok Library. The population in this study were users of the Library and Archives Service of Barito Selatan, Central Kalimantan until August 2019, totaling 517 people. The samples in this study used a simple random sampling technique. The size of the minimum sample size is determined by the Slovin formula to obtain 84 visitors. Furthermore, the researcher will take a sample of 100 visitors. Data retrieval in this study was carried out with a technical questionnaire, using the exedental sampling technique. The answer score is determined based on a Likert scale. The variables put forward in this study are the factors of service quality and visitor satisfaction. The data analysis technique used in this research is descriptive research data and validity and reliability tests.

\section{HASIL PENELITIAN DAN PEMBAHASAN}

Based on the scores of respondents' answers to the questionnaires that have been distributed, results are obtained that describe a description of each research factor.

\section{Quality of Service}

The results of the respondents' answers to the tangible service quality factors are as follows;

Table-1: Calculation of Respondents' Answers Regarding Service Quality Factors Based on Direct Evidence (Tangible)

\begin{tabular}{|c|c|c|c|c|c|}
\hline No. & Question Items & Answer & $\begin{array}{l}\text { Total } \\
\text { (person) }\end{array}$ & $\begin{array}{l}\text { Percentage } \\
(\%)\end{array}$ & $\begin{array}{l}\text { Total } \\
\text { Score }\end{array}$ \\
\hline \multirow[t]{5}{*}{1.} & \multirow{5}{*}{$\begin{array}{l}\text { The library location is strategic and } \\
\text { easy to reach }\end{array}$} & Very Strategic & 21 & 21 & \multirow[t]{5}{*}{347} \\
\hline & & Strategic & 27 & 27 & \\
\hline & & Quite strategic & 33 & 33 & \\
\hline & & Not Strategic & 16 & 16 & \\
\hline & & Not Very Strategic & 3 & 3 & \\
\hline \multirow[t]{5}{*}{2.} & \multirow{5}{*}{$\begin{array}{l}\text { Adequate library facilities (parking, air } \\
\text { conditioning, library chairs, TV \& } \\
\text { toilet) }\end{array}$} & Very Adequate & 11 & 11 & \multirow[t]{5}{*}{320} \\
\hline & & Adequate & 34 & 34 & \\
\hline & & Quite adequate & 26 & 26 & \\
\hline & & Not Adequate & 22 & 22 & \\
\hline & & Not Very Adequate & 7 & 7 & \\
\hline \multirow[t]{5}{*}{3.} & \multirow[t]{5}{*}{ Comfortable library room atmosphere } & Very comfortable & 8 & 8 & \multirow[t]{5}{*}{325} \\
\hline & & Comfortable & 35 & 35 & \\
\hline & & Quite comfortable & 37 & 37 & \\
\hline & & Not comfortable & 14 & 14 & \\
\hline & & Not Very comfortable & 6 & 6 & \\
\hline \multicolumn{5}{|c|}{ Accumulated Total Score } & 992 \\
\hline
\end{tabular}

Source: Results of data processing, 2020

Based on table 1, we can see the answers of respondents who mostly stated that the library has a strategic location and already has adequate library facilities, as well as a comfortable atmosphere in the library room. However, some respondents said that the location of the library is not very strategic, this is because the location of the residence or domicile of the respondent is relatively far away so that it takes a long time to get to the library. Apart from that, several respondents also said that the library facilities were very inadequate and the library space was very uncomfortable. This is because the library room has a limited area, so some visitors cannot take advantage of these facilities, such as chairs in the reading room or waiting room, only 3 toilets for the entire library, and parking locations far from the library entrance. So it makes users feel uncomfortable. However, overall the service quality from direct evidence is quite good.

Based on the survey results above, it shows that the quality of service from the indicators of direct evidence (tangible) greatly affects user satisfaction. Increasing satisfaction of visitors The Library and Archives Office of Barito Selatan Regency, Central Kalimantan, must prioritize improving service quality based on direct evidence, such as increasing the convenience of parking facilities, air conditioning, chairs, TV, and toilets, as well as the comfort of the room or waiting room for visitors.

The results of respondents' answers regarding service quality based on reliability are as follows; 
Anna Pranita Br Saragih et al., Sch Int J Law Crime Justice, Feb, 2021; 4(2): 89-96

Table-2: Calculation of Respondents' Answers Regarding Service Quality Based on Reliability

\begin{tabular}{|c|c|c|c|c|c|}
\hline No. & Question Items & Answer & Total (person) & Percentage (\%) & Total Score \\
\hline \multirow[t]{5}{*}{1.} & \multirow{5}{*}{$\begin{array}{l}\text { The library has complete } \\
\text { information about the library book } \\
\text { collection }\end{array}$} & Very complete & 18 & 18 & \multirow[t]{5}{*}{326} \\
\hline & & Complete & 28 & 28 & \\
\hline & & Quite complete & 25 & 25 & \\
\hline & & Not complete & 20 & 20 & \\
\hline & & Not very complete & 9 & 9 & \\
\hline \multirow[t]{5}{*}{2.} & \multirow{5}{*}{$\begin{array}{l}\text { The administration process for } \\
\text { submitting library membership is } \\
\text { easy }\end{array}$} & Very easy & 22 & 22 & \multirow[t]{5}{*}{334} \\
\hline & & Easy & 32 & 32 & \\
\hline & & Quite easy & 15 & 15 & \\
\hline & & Not easy & 20 & 20 & \\
\hline & & Not very easy & 11 & 11 & \\
\hline \multirow[t]{5}{*}{3.} & \multirow{5}{*}{$\begin{array}{l}\text { The library does not stipulate a } \\
\text { guarantee for members to borrow } \\
\text { books }\end{array}$} & Very agree & 24 & 24 & \multirow[t]{5}{*}{345} \\
\hline & & Agree & 29 & 29 & \\
\hline & & Quite agree & 25 & 25 & \\
\hline & & Not agree & 12 & 12 & \\
\hline & & Not very agree & 10 & 10 & \\
\hline \multicolumn{5}{|c|}{ Accumulated Total Score } & 1005 \\
\hline
\end{tabular}

Source: Results of data processing, 2020

Based on the table, it can be seen that the respondents' answers regarding service quality based on reliability show that most of the respondents stated that the library has information about a complete library book collection and the administration process for submitting library membership applications is easy. In addition, most of the respondents agreed that the library did not stipulate a guarantee for members to borrow books. However, a small proportion of respondents gave the opinion that the library book collection was very incomplete and the administrative process for library membership applications was not easy. This is reviewed based on the needs of each different user, where each user has a variety of literary needs so that not all of the library's needs can be fulfilled by the library. In addition, new users that do not carry the necessary requirements to become members cause users to have to fulfill them at a later date. Some respondents also stated that libraries should determine guarantees for members in borrowing books. This is actually an existing provision, whereby new users are required to provide guarantees in the form of a relatively affordable amount of money. The guarantee will be returned after the user returns the book. As for the next borrowing process, users are not subject to a guarantee obligation. Overall, the library service quality from the reliability indicator is quite good.

Service quality based on service reliability is a common thing for users, where libraries are supposed to have complete information about library book collections, easy membership submission processes, and do not stipulate guarantees for readers who borrow books. The increase or decrease in service quality based on this reliability has a direct impact on user satisfaction.

The results of respondents' answers regarding service quality based on responsiveness are as follows;

Table-3: Calculation of Respondents' Answers Regarding Service Quality Based on Responsiveness

\begin{tabular}{|c|c|c|c|c|c|}
\hline No. & Question Items & Answer & Total (person) & Percentage (\%) & Total Score \\
\hline \multirow[t]{5}{*}{1.} & \multirow{5}{*}{$\begin{array}{l}\text { Employees can understand } \\
\text { the needs of visitors }\end{array}$} & Very understanding & 27 & 27 & \multirow[t]{5}{*}{346} \\
\hline & & Understanding & 22 & 22 & \\
\hline & & Quite understanding & 26 & 26 & \\
\hline & & Not understanding & 20 & 20 & \\
\hline & & Very clueless & 5 & 5 & \\
\hline \multirow[t]{5}{*}{2.} & \multirow{5}{*}{$\begin{array}{l}\text { Library staff serve visitors } \\
\text { quickly }\end{array}$} & Very agree & 20 & 20 & \multirow[t]{5}{*}{331} \\
\hline & & Agree & 20 & 20 & \\
\hline & & Quite agree & 37 & 37 & \\
\hline & & Not agree & 17 & 17 & \\
\hline & & Not very agree & 6 & 6 & \\
\hline \multirow[t]{5}{*}{3.} & \multirow{5}{*}{$\begin{array}{l}\text { Library staff handle library } \\
\text { problems appropriately }\end{array}$} & Very agree & 18 & 18 & \multirow[t]{5}{*}{328} \\
\hline & & Agree & 23 & 23 & \\
\hline & & Quite agree & 31 & 31 & \\
\hline & & Not agree & 25 & 25 & \\
\hline & & Not very agree & 3 & 3 & \\
\hline \multicolumn{5}{|c|}{ Accumulated Total Score } & 1005 \\
\hline
\end{tabular}


Based on Table-3, it can be seen that the answers of respondents regarding service quality are based on responsiveness which shows that most of the respondents stated that library employees can understand the needs of visitors and serve users quickly. Apart from that, the respondents also stated that the library staff handled the problems of the visitors appropriately. However, a small proportion of respondents gave the opinion that employees really did not understand the needs of visitors and did not serve users quickly, and did not handle user problems appropriately. This is because not all library employees have a duty to serve users by providing the necessary information so that users must convey their needs to the library administration department. In addition, there are queues from library services in providing information, searching for books and literature, as well as the administration of users that must be checked carefully, making other users have to wait to get services according to their needs and there is limited knowledge of library staff on parts that are not their duties. mainly, so that sometimes some of the information conveyed to users is not quite right. Overall, the quality of library services from the indicators of responsiveness (Responsiveness) is quite good. Based on the results of this study, there is an influence between service quality and library satisfaction. So to increase the satisfaction of visitors, the Office of Library and Archives of Barito Selatan Regency, Central Kalimantan, must prioritize improving service quality based on service reliability, namely by understanding the needs of prospective users, serving users quickly, and addressing user problems appropriately.

The results of the respondents' answers regarding service quality based on assurance and assurance are as follows;

Table-4: Calculation of Respondents' Answers Regarding Service Quality Based on Guarantee and Assurance

\begin{tabular}{|c|c|c|c|c|c|}
\hline No. & Question Items & Answer & $\begin{array}{l}\text { Total } \\
\text { (person) }\end{array}$ & $\begin{array}{l}\text { Percentage } \\
(\%)\end{array}$ & $\begin{array}{l}\text { Total } \\
\text { Score }\end{array}$ \\
\hline \multirow[t]{5}{*}{1.} & \multirow{5}{*}{$\begin{array}{l}\text { Library employees can be trusted in carrying } \\
\text { out their duties to handle the needs of users }\end{array}$} & Very agree & 13 & 13 & \multirow[t]{5}{*}{321} \\
\hline & & Agree & 28 & 28 & \\
\hline & & Quite agree & 35 & 35 & \\
\hline & & Not agree & 15 & 15 & \\
\hline & & Not very agree & 9 & 9 & \\
\hline \multirow[t]{5}{*}{2.} & \multirow{5}{*}{$\begin{array}{l}\text { Employee knowledge about the library's book } \\
\text { collection }\end{array}$} & Very good & 16 & 16 & \multirow[t]{5}{*}{309} \\
\hline & & Good & 25 & 25 & \\
\hline & & Quite good & 24 & 24 & \\
\hline & & Not good & 22 & 22 & \\
\hline & & Not very good & 13 & 13 & \\
\hline \multirow[t]{5}{*}{3.} & \multirow{5}{*}{$\begin{array}{l}\text { Users feel safe in the process of borrowing } \\
\text { books from the library }\end{array}$} & Very agree & 12 & 12 & \multirow[t]{5}{*}{299} \\
\hline & & Agree & 19 & 19 & \\
\hline & & Quite agree & 36 & 36 & \\
\hline & & Not agree & 22 & 22 & \\
\hline & & Not very agree & 11 & 11 & \\
\hline \multicolumn{4}{|c|}{ Accumulated Total Score } & 929 & \\
\hline
\end{tabular}

Source: Results of data processing, 2020

Based on Table 4, it can be seen that the respondents' answers regarding service quality based on assurance and certainty show that most of the respondents stated that library employees can be trusted in handling the needs of visitors and employees have good knowledge about the collection of books owned by the library and users feel safe in carrying out the borrowing process. book. However, a small proportion of respondents said they did not trust library employees in handling the needs of visitors and the employees' lack of knowledge about the library's book collections and respondents felt insecure in carrying out the process of borrowing books from the library. This happens because of the inaccuracy of library staff in handling library problems, such as the need for books that are desired by visitors and other information and the limitations of duties and responsibilities that are handled by library employees, so that if one of the employees is not present or is carrying out other tasks and needs, then other employees will be very constrained in replacing the main task of the library service. Overall, the quality of library services from the indicators of assurance and certainty is quite good.

Based on the results of this study indicate that service quality based on assurance and certainty affects visitor satisfaction. So to increase visitor satisfaction, it is necessary to provide direction to the staff of the Barito Selatan Regency, Central Kalimantan Library and Archives to be trusted in carrying out the task of handling users, increasing employee knowledge about library book collections, and providing a sense of security for users in borrowing books. 
Anna Pranita Br Saragih et al., Sch Int J Law Crime Justice, Feb, 2021; 4(2): 89-96

The results of respondents' answers regarding service quality based on empathy are as follows;

Table-5: Calculation of Respondents' Answers Regarding Service Quality Based on Empathy

\begin{tabular}{|c|c|c|c|c|c|}
\hline No. & Question Items & Answer & $\begin{array}{l}\begin{array}{l}\text { Total } \\
\text { (person) }\end{array} \\
\end{array}$ & $\begin{array}{l}\text { Percentage } \\
(\%)\end{array}$ & Total Score \\
\hline \multirow[t]{5}{*}{1.} & \multirow{5}{*}{$\begin{array}{l}\text { The attention given by library } \\
\text { employees to the visitors }\end{array}$} & Very good & 23 & 23 & \multirow{5}{*}{326} \\
\hline & & Good & 22 & 22 & \\
\hline & & Quite good & 23 & 23 & \\
\hline & & Not good & 22 & 22 & \\
\hline & & Not very good & 10 & 10 & \\
\hline \multirow[t]{5}{*}{2.} & \multirow{5}{*}{$\begin{array}{l}\text { Attitudes of library employees to } \\
\text { visitors }\end{array}$} & Very sympathetic & 29 & 29 & \multirow[t]{5}{*}{343} \\
\hline & & Sympathetic & 21 & 21 & \\
\hline & & Quite sympathetic & 22 & 22 & \\
\hline & & Not sympathetic & 20 & 20 & \\
\hline & & Not very sympathetic & 8 & 8 & \\
\hline \multirow[t]{5}{*}{3.} & \multirow{5}{*}{$\begin{array}{l}\text { Employees can handle problems } \\
\text { experienced by users patiently }\end{array}$} & Very agree & 23 & 23 & \multirow[t]{5}{*}{329} \\
\hline & & Agree & 23 & 23 & \\
\hline & & Quite agree & 23 & 23 & \\
\hline & & Not agree & 22 & 22 & \\
\hline & & Not very agree & 9 & 9 & \\
\hline \multicolumn{5}{|c|}{ Accumulated Total Score } & 998 \\
\hline
\end{tabular}

Source: Results of data processing, 2020

Based on Table 5, it can be seen that the answers of respondents regarding service quality are based on empathy which shows that most of the respondents stated that the attention given by library employees to users was very good. The attitude of the library staff to the visitors is also quite sympathetic and patient enough in dealing with the problems faced by the users. However, a small proportion of respondents gave the opinion that library employees were not attentive and were not sympathetic to readers. This is because library employees do not fully understand what the library needs and sometimes library employees in serving the needs of users speak too loudly with a slightly high intonation tone, so that the user responds as an unpleasant attitude. Besides, several respondents gave the opinion that employees could not patiently handle problems experienced by users. This is because at certain times the library employees are busy with the implementation of important duties and obligations in library management, so that sometimes the employee's response to the library is not good. Overall, the quality of library services from the empathy indicator is quite good.

Based on the explanation above, there is an effect of service quality based on empathy on visitor satisfaction. So to increase the satisfaction of visitors, the Library and Archives Service of Barito Selatan Regency, Central Kalimantan, must prioritize improving service quality based on service empathy, namely by providing directions to all employees of the Barito Selatan Regency Central Kalimantan Library and Archives Service so that they can pay good attention to users, be sympathetic, and handle user problems patiently.

\section{Customer Satisfaction (Y)}

The results of the respondents' answers to the visitor satisfaction factor (Y) are divided into 3 indicators, where each indicator has several questions. The results of respondents' answers to the visitor satisfaction factor, on the overall satisfaction indicator are as follows;

Table-6: Calculation of Respondents' Answers on Customer Satisfaction Factors Based on Overall Satisfaction

\begin{tabular}{|c|c|c|c|c|c|}
\hline No. & Question Items & Answer & $\begin{array}{l}\text { Total } \\
\text { (person) }\end{array}$ & $\begin{array}{l}\text { Percentage } \\
(\%)\end{array}$ & Total Score \\
\hline \multirow[t]{5}{*}{1.} & \multirow{5}{*}{$\begin{array}{l}\text { The process of library services } \\
\text { provided to visitors according to their } \\
\text { wishes }\end{array}$} & Very satisfied & 19 & 19 & \multirow[t]{5}{*}{326} \\
\hline & & Satisfied & 22 & 22 & \\
\hline & & Quite satisfied & 35 & 35 & \\
\hline & & Not satisfied & 14 & 14 & \\
\hline & & Very not satisfied & 10 & 10 & \\
\hline \multirow[t]{5}{*}{2.} & \multirow{5}{*}{$\begin{array}{l}\text { The service process provided is as } \\
\text { needed }\end{array}$} & Very satisfied & 15 & 15 & \multirow[t]{5}{*}{343} \\
\hline & & Satisfied & 37 & 37 & \\
\hline & & Quite satisfied & 28 & 28 & \\
\hline & & Not satisfied & 16 & 16 & \\
\hline & & Very not satisfied & 4 & 4 & \\
\hline \multicolumn{5}{|c|}{ Accumulated Total Score } & 669 \\
\hline
\end{tabular}

Source: Results of data processing, 2020 
Respondents' answers to the overall satisfaction indicator can be seen in Table 6 which shows that most respondents feel quite satisfied with the library service process provided to users according to their wishes and as needed. Although there were several respondents who expressed their dissatisfaction .This is because the needs of visitors who come to the library are different, where not all the needs of the library can be handled by library staff. For example, the need for a complete reference on regional culture, or a reference to fields of activity such as agriculture, plantation, or about society. Based on the total value of the visitor satisfaction variable from the Overall satisfaction indicator, the resulting total score is 669 with the category quite satisfied.

The results of respondents' answers to visitor satisfaction factors, on the indicators of satisfaction based on expectations (expectation satisfaction) are as follows;

Table-7: Calculation of Respondents' Answers on Customer Satisfaction Factors Based on Expectations (Expectation satisfaction)

\begin{tabular}{|c|c|c|c|c|c|}
\hline No. & Question Items & Answer & $\begin{array}{l}\text { Total } \\
\text { (person) }\end{array}$ & $\begin{array}{l}\text { Percentage } \\
(\%)\end{array}$ & $\begin{array}{l}\text { Total } \\
\text { Score }\end{array}$ \\
\hline \multirow[t]{5}{*}{1.} & \multirow{5}{*}{$\begin{array}{l}\text { The visitor is satisfied because the } \\
\text { service process is efficient }\end{array}$} & Very satisfied & 20 & 20 & \multirow[t]{5}{*}{313} \\
\hline & & Satisfied & 10 & 10 & \\
\hline & & Quite satisfied & 38 & 38 & \\
\hline & & Not satisfied & 27 & 27 & \\
\hline & & Very not satisfied & 5 & 5 & \\
\hline \multirow[t]{5}{*}{2.} & \multirow{5}{*}{$\begin{array}{l}\text { The visitor is satisfied because the } \\
\text { service process is effective }\end{array}$} & Very satisfied & 18 & 18 & \multirow[t]{5}{*}{327} \\
\hline & & Satisfied & 23 & 23 & \\
\hline & & Quite satisfied & 30 & 30 & \\
\hline & & Not satisfied & 26 & 26 & \\
\hline & & Very not satisfied & 3 & 3 & \\
\hline \multicolumn{5}{|c|}{ Accumulated Total Score } & 640 \\
\hline
\end{tabular}

Source: Results of data processing, 2020

Based on table 7 , we can see that the respondents were quite satisfied with the service process provided effectively and efficiently. However, some respondents stated that the services provided were ineffective and efficient, causing dissatisfaction with users. This is due to the limitations of the library in handling the number of users, while the number of service employees is only able to provide services to a limited number of users. Also, it is caused by the limited number of items in each library collection so that some users do not get reading material, and have to wait for the use of reading material from other readers. Based on the total value of the visitor satisfaction variable from the Expectation satisfaction indicator, the resulting total score is 640 with the category quite satisfied.

The results of respondents' answers to user satisfaction factors, on the indicators of satisfaction based on trust (experience satisfactions) are as follows;

Table-8: Calculation of Respondents' Answers on Customer Satisfaction Factors Based on Trust (Expeience Satisfactions)

\begin{tabular}{|c|c|c|c|c|c|}
\hline No. & Question Items & Answer & $\begin{array}{l}\text { Total } \\
\text { (person) }\end{array}$ & $\begin{array}{l}\text { Percentage } \\
(\%)\end{array}$ & $\begin{array}{l}\text { Total } \\
\text { Score }\end{array}$ \\
\hline \multirow[t]{5}{*}{1.} & \multirow{5}{*}{$\begin{array}{l}\text { Users have confidence in the service } \\
\text { process provided }\end{array}$} & Very satisfied & 19 & 19 & \multirow[t]{5}{*}{322} \\
\hline & & Satisfied & 21 & 21 & \\
\hline & & Quite satisfied & 30 & 30 & \\
\hline & & Not satisfied & 23 & 23 & \\
\hline & & Very not satisfied & 7 & 7 & \\
\hline \multirow[t]{5}{*}{2.} & \multirow{5}{*}{$\begin{array}{l}\text { Users can rely on the service process } \\
\text { provided for their purposes }\end{array}$} & Very satisfied & 18 & 18 & \multirow[t]{5}{*}{308} \\
\hline & & Satisfied & 11 & 11 & \\
\hline & & Quite satisfied & 40 & 40 & \\
\hline & & Not satisfied & 23 & 23 & \\
\hline & & Very not satisfied & 8 & 8 & \\
\hline \multicolumn{5}{|c|}{ Accumulated Total Score } & 630 \\
\hline
\end{tabular}

Source: Results of data processing, 2020 
Anna Pranita Br Saragih et al., Sch Int J Law Crime Justice, Feb, 2021; 4(2): 89-96

Based on table 8 , it can be seen that the respondents' answers to the indicators of satisfaction based on trust (experience satisfactions) that most of the respondents stated that they were quite satisfied that library users had confidence in the service process provided and library users could rely on the service process provided for their needs. Although some respondents gave a very dissatisfied opinion that users had confidence in the service process provided and could rely on the service process provided for their needs. This is considered by the library users because the library service systems and procedures have not been maximally formed, such as the use of information technology and automation. And library resources are still not able to meet all the needs of users.

Based on the total value of the customer satisfaction variable from the indicator of trust (Expeience satisfactions), the resulting total score is 630 with the category quite satisfied. Based on the three indicators, the total score of visitor satisfaction was 1939 with the category quite satisfied. So it can be said that the respondents are quite satisfied with the quality of library services to users at the Library and Archives Service of Barito Selatan Regency, Central Kalimantan.

\section{Validity and Reliability Test}

The results of the calculation show that all question items in the research instrument can be declared valid because the $r_{\text {count }}$ value is greater than the value 0.3 . Measurement of reliability was carried out using the Alfha Cronbach coefficient $(\alpha)$. The reliability of an instrument can be accepted if it has a Cronbach's Alpa at least 0.6. Based on the results of the reliability test on distributed questionnaires, it was found that all factors or items were reliable because they had an Alpha greater than 0.6. So it can be stated that all question items are valid and reliable.

\section{CONCLUSION}

Based on the research results that have been stated, it can be concluded that the quality of library services based on indicators of direct evidence (tangible), reliability, responsiveness (assurance), and empathy is quite good. Likewise, the level of customer satisfaction based on indicators of overall satisfaction, expectations satisfaction, and trust satisfaction (expeience) is quite satisfied.

\section{REFERENCES}

1. Tjiptono, Fandy. 2012. Strategi Bisnis. Yogyakarta : Andi.

2. Lupiyoadi, Rambat. 2006. Manajemen Pemasaran Jasa : Teori dan Praktek. Jakarta: PT Salemba Empat.

3. Supranto, J. 2011. Pengukuran Tingkat Kepuasan Pelanggan untuk Menaikan Pangsa Pasar. Jakarta: Rineka Cipta.

4. Khairunnas, dan Sofjan Assauri. 2011. Analisis Pengaruh Brand Identity Design Terhadap Proses Pembentukan Brand Awareness: studi kasus: Nordhenbasic. Manajemen Usahawan Indonesia, Vol. 41 No. 1 Januari-Februari, 2011.

5. Indonesia, P. N. R. (2007). Undang-Undang Republik Indonesia Nomor 43 Tahun 2007 Tentang Perpustakaan. 